\title{
The Effect of Yeast Fermentation of Two Lupine Species on the Digestibility of Protein and Amino Acids, Microflora Composition and Metabolites Production in the Ileum of Growing Pigs
}

\author{
Małgorzata Kasprowicz-Potocka ${ }^{1, *(\mathbb{D}}$, Anita Zaworska-Zakrzewska ${ }^{1}\left(\mathbb{D}\right.$, Marcin Taciak $\left.^{2}{ }^{(}\right)$and $^{-}$ \\ Andrzej Frankiewicz ${ }^{1}$
}

1 Department of Animal Nutrition, Faculty of Veterinary Medicine and Animal Sciences, Poznan University of Life Sciences, Wołyńska 33, 60-637 Poznan, Poland; anita.zaworska-zakrzewska@up.poznan.pl (A.Z.-Z.); andrzej.frankiewicz@up.poznan.pl (A.F.)

2 Department of Animal Nutrition, The Kielanowski Institute of Animal Physiology and Nutrition, Polish Academy of Sciences, Instytucka 3, 05-110 Jabłonna, Poland; m.taciak@ifzz.pl

* Correspondence: malgorzata.potocka@up.poznan.pl; Tel.: +48-61-8487722; Fax: +48-61-8487226

Citation: Kasprowicz-Potocka, M.; Zaworska-Zakrzewska, A.; Taciak, M.; Frankiewicz, A. The Effect of Yeast Fermentation of Two Lupine Species on the Digestibility of Protein and Amino Acids, Microflora Composition and Metabolites Production in the Ileum of Growing Pigs. Animals 2021, 11, 2894. https://doi.org/10.3390/ ani11102894

Academic Editor: Eugeniusz R. Grela

Received: 1 September 2021

Accepted: 1 October 2021

Published: 4 October 2021

Publisher's Note: MDPI stays neutral with regard to jurisdictional claims in published maps and institutional affiliations.

Copyright: (c) 2021 by the authors. Licensee MDPI, Basel, Switzerland. This article is an open access article distributed under the terms and conditions of the Creative Commons Attribution (CC BY) license (https:/ / creativecommons.org/licenses/by/ $4.0 /)$.
Simple Summary: The fermented feed component in pigs' diet may influence the microbiota of the gastrointestinal tract, improve the use of nutrients from the diet, and reduce the level of excreted $\mathrm{N}$ and $\mathrm{P}$. The aim of this study was to investigate the effects of raw and Candida utilis-fermented yellow and narrow-leaved lupine seeds on the apparent ileal digestibility coefficients of protein and amino acids and the metabolic activity of the intestinal microflora in five cannulated male pigs. Fermentation significantly improved the ileal digestibility of protein, asparagine, threonine, tyrosine, histidine, and arginine in the lupine seeds and increased the counts of total bacteria and yeast, the $\mathrm{pH}$ value, isobutyrate and isovalerate concentrations in the ileal digesta, but decreased the dry matter and ammonia content. The narrow-leaved lupine seeds were characterized by higher digestibility of asparagine, threonine, serine, alanine, valine, isoleucine, and arginine. The digesta of the pigs fed with these seeds had higher counts of lactic acid bacteria and moulds but lower total bacteria count than the digesta of the pigs fed with yellow lupine seeds.

Abstract: The aim of this study was to investigate the effects of raw and Candida utilis-fermented yellow (YL) and narrow-leaved lupine (NL) seeds on the apparent ileal digestibility coefficients (AID) of protein and amino acids in pigs and the metabolic activity of their intestinal microflora. Five cross-bred castrated 25-kg barrows were surgically fitted with a T-cannula in the distal ileum and housed individually in metabolic cages. They were fed five semi-synthetic diets containing only one source of protein: soybean meal (SBM), raw or fermented yellow lupine seeds (RYL or FYL), raw or fermented narrow-leaved lupine seeds (RNL or FNL). The study period consisted of six-day adaptation to the diet and one-day collection of digesta, which was sampled for microbial and chemical analyses. The AID coefficients of protein and amino acids were calculated with the marker method with $\mathrm{TiO}_{2}$. One-way (feed effect) and two-way (variety effect, fermentation effect) analysis of variance (ANOVA) with Duncan's test at $p<0.05$ were applied. The digesta from the SBM and FNL variants had significantly higher $(p<0.05)$ AID coefficients of protein, asparagine, threonine, serine, isoleucine, leucine, histidine, and tyrosine, whereas the SBM variant was characterized by the lowest AID of cystine and the highest AID of alanine and methionine $(p<0.05)$. The ileal digesta of the pigs fed with FYL contained more bacteria, whereas the count of yeast was higher in the FNL variant. The digesta of the pigs from the FNL and RYL variants had the highest count of moulds $(p<0.05)$, whereas the digesta in the FYL, SBM, and RNL variants had almost no moulds at all. The ileal dry matter content was significantly lower in SBM group. The lowest $\mathrm{pH}$ was noted in the RYL variant $(p<0.05)$. The content of ammonia and total volatile fatty acids in the ileal digesta of the SBM variant was the lowest $(p<0.05)$. Fermentation significantly improved the AID of protein, asparagine, threonine, tyrosine, histidine, and arginine, increased the counts of total bacteria and yeast, the $\mathrm{pH}$ value, and isobutyrate and isovalerate concentrations, but decreased the dry matter and ammonia 
content $(p<0.05)$. The digesta of the NL variants was characterized by higher AID of asparagine, threonine, serine, alanine, valine, isoleucine, and arginine, and higher counts of LAB and moulds but lower total bacteria count than in the YL variants. The ileal $\mathrm{pH}$ was lower in the YL variants, where higher isobutyrate and butyrate concentrations $(p<0.05)$ were observed. To sum up, fermentation increased the counts of the ileal microbiota and improved the digestibility coefficients of protein and some amino acids. The narrow-leaved lupine seeds resulted in more positive changes in the digesta of growing pigs than yellow lupine.

Keywords: Candida utilis; fermentation; lupine; pigs; digestibility; microflora

\section{Introduction}

Fermented feeds have become popular as good quality components of diets and as functional food which could be beneficial for consumer health [1-3]. Fermented products contain not only proteins, minerals, and vitamins but also living or dried cells of lactic acid bacteria or yeast, which can affect probiotically or prebiotically the digestive tract microflora $[4,5]$. The supplementation of the diet with fermented components has beneficial effect on the growth of pigs and regulation of the intestinal microflora because it improves the digestibility of protein and amino acids, and it reduces the concentration of antinutritional factors [3,6-9]. Currently, soybean meal (SBM) is a basic high-protein component used in the production of complete diets for pigs. However, as the climate in Europe is rather unsuitable to grow soy; soybean meal is usually imported, so its price is high. The EU is concerned about the possibilities of reducing the SBM level in diets for pigs and poultry [10-13]. Legume seeds and their products could replace soybean meal totally or partially, but unprocessed seeds contain many antinutritional substances (ANFs) such as alkaloids, phytate, and oligosaccharides, which may negatively influence the availability and utilization of nutrients by monogastric animals [14-16]. Fermentation with different microorganisms can reduce ANFs to a safe level. The products are characterized by acidic $\mathrm{pH}$ and the dominance of lactic and propionic acids, which are beneficial for the gastrointestinal microflora, especially in young pigs $[14,17]$. After fermentation, lupine seeds are more suitable for animals and they could replace SBM in the diet. So far there have been only a few studies on the nutritional value and physiological properties of fermented lupine seeds used for animal nutrition $[14,17,18]$. The following research hypothesis was assumed: the fermentation of lupine seeds improves their nutritional value, increases the digestibility of nutritional components and positively influences the ecosystem of the pig's gastrointestinal tract. The ileal digestibility coefficients of amino acids are also necessary to calculate the right balance of amino acids in the feed ration for pigs. This study presents the effects of raw and Candida utilis-fermented yellow and narrow-leaved lupine seeds on the pigs' digestibility coefficients of amino acids and protein in the ileum and the metabolic activity of the pigs' intestinal microflora.

\section{Materials and Methods}

\subsection{Lupine Seeds and Fermentation Process}

The seeds of Lupinus luteus (var. Lord) and Lupinus angustifolius (var. Graf) were obtained from the Plant Breeding Station in Przebedowo, Poland. The Candida utilis strain was bought from the Pure Culture Collection of Industrial Microorganisms LOCK 105 at the Institute of Fermentation Technology and Microbiology, Łódź University of Technology, Poland. Fermented yellow and narrow-leaved lupine seed products were obtained in the process described by Kasprowicz-Potocka et al. [7]. The raw seeds and fermented products were characterized in Tables 1 and 2. 
Table 1. The chemical composition of raw and fermented lupine seeds.

\begin{tabular}{ccccc}
\hline & \multicolumn{2}{c}{ Raw Seeds } & \multicolumn{2}{c}{ Fermented Seeds } \\
\cline { 2 - 5 } Item \% & $\begin{array}{c}\text { Narrow-Leaved } \\
\text { Lupine }\end{array}$ & Yellow Lupine & $\begin{array}{c}\text { Narrow-Leaved } \\
\text { Lupine }\end{array}$ & Yellow Lupine \\
\hline Dry matter & $87.94 \pm 0.02$ & $88.6 \pm 0.22$ & $96.33 \pm 0.04$ & $94.99 \pm 0.13$ \\
Crude protein & $31.5 \pm 0.6$ & $37.3 \pm 0.5$ & $35.7 \pm 0.2$ & $47.0 \pm 0.3$ \\
Lysine & $1.29 \pm 0.02$ & $1.65 \pm 0.01$ & $1.54 \pm 0.02$ & $2.02 \pm 0.01$ \\
Methionine & $0.16 \pm 0.01$ & $0.20 \pm 0.02$ & $0.10 \pm 0.01$ & $0.17 \pm 0.01$ \\
Cystine & $0.36 \pm 0.04$ & $0.71 \pm 0.02$ & $0.64 \pm 0.02$ & $0.90 \pm 0.01$ \\
Threonine & $0.94 \pm 0.05$ & $1.08 \pm 0.03$ & $1.02 \pm 0.01$ & $1.24 \pm 0.03$ \\
Crude ash & $3.4 \pm 0.1$ & $4.2 \pm 0.1$ & $3.5 \pm 0.1$ & $4.5 \pm 0.1$ \\
ADF & $19.9 \pm 0.2$ & $18.7 \pm 0.9$ & $19.7 \pm 0.5$ & $16.1 \pm 0.4$ \\
NDF & $24.7 \pm 0.1$ & $24.5 \pm 1.0$ & $21.1 \pm 0.7$ & $18.9 \pm 1.3$ \\
Total alkaloids & $0.007 \pm 0.001$ & $0.016 \pm 0.001$ & $0.021 \pm 0.003$ & $0.042 \pm 0.003$ \\
Total RFOs & $6.6 \pm 0.2$ & $7.9 \pm 0.3$ & $0.0 \pm 0.0$ & $0.0 \pm 0.0$ \\
Phytate phosphorus & $0.36 \pm 0.07$ & $0.59 \pm 0.03$ & $0.12 \pm 0.01$ & $0.42 \pm 0.09$
\end{tabular}

The results are expressed as mean values \pm standard deviation; ADF-acid detergent fiber; NDF-neutral detergent fiber; RFOs—oligosaccharides raffinose family.

Table 2. The microbial status of raw and fermented lupine seeds.

\begin{tabular}{ccccc}
\hline \multirow{2}{*}{ Item CFU/g } & \multicolumn{2}{c}{ Raw Seeds } & \multicolumn{2}{c}{ Fermented Seeds } \\
\cline { 2 - 5 } & $\begin{array}{c}\text { Narrow-Leaved } \\
\text { Lupine }\end{array}$ & Yellow Lupine & $\begin{array}{c}\text { Narrow-Leaved } \\
\text { Lupine }\end{array}$ & Yellow Lupine \\
\hline pH & $5.5 \pm 0.1$ & $5.6 \pm 0.2$ & $4.11 \pm 0.1$ & $3.98 \pm 0.1$ \\
Total bacteria & $5.4 \times 10^{5} \pm 1.1 \times 10^{2}$ & $4.6 \times 10^{5} \pm 1.4 \times 10^{3}$ & $2.5 \times 10^{6} \pm 1.4 \times 10^{3}$ & $8.4 \times 10^{5} \pm 1.1 \times 10^{3}$ \\
Lactic acid bacteria & $2.4 \times 10^{4} \pm 7.1 \times 10^{2}$ & $3.9 \times 10^{4} \pm 1.2 \times 10^{2}$ & $4.8 \times 10^{5} \pm 3.1 \times 10^{3}$ & $7.0 \times 10^{5} \pm 1.1 \times 10^{3}$ \\
Yeast & $2.3 \times 10^{4} \pm 9.9 \times 10^{2}$ & $3.7 \times 10^{3} \pm 1.1 \times 10^{2}$ & $4.0 \times 10^{6} \pm 1.1 \times 10^{4}$ & $3.4 \times 10^{6} \pm 2.1 \times 10^{3}$ \\
Coliform bacteria & $5.5 \times 10^{4} \pm 2.4 \times 10^{2}$ & $7.5 \times 10^{4} \pm 4.2 \times 10^{2}$ & $1.5 \times 10^{3} \pm 1.4 \times 10^{2}$ & $1.5 \times 10^{4} \pm 9.1 \times 10^{2}$ \\
\hline
\end{tabular}

\subsection{Experiment on Animals}

All the experimental procedures complied with the guidelines of the Local Ethical Committee for Experiments on Animals in Poznań (43/2011) regarding animal experimentation and care and they followed the EU Directive 2010/63/EU on the protection of animals used for scientific purposes. The pigs received all the necessary veterinary vaccinations and had unlimited access to water.

Five cross-bred castrated barrows with an average initial body weight of about $25 \mathrm{~kg}$ were surgically fitted with a T-cannula in the distal ileum, following the method described by van Leeuwen et al. [19]. After ten-day recuperation each of the pigs was housed in an individual metabolic cage and was randomly allotted to a split-plot model with five diets and five experimental periods. All diets were semi-synthetic and contained only one source of protein: soybean meal (SBM), raw yellow (RYL) or fermented yellow lupine seeds (FYL), raw narrow-leaved (RNL) or fermented narrow-leaved lupine seeds (FNL) at an amount resulting from the protein content in the components (Table 3). The diets were supplemented with starch, sugar, and soybean oil. All diets also contained $3 \mathrm{~g} / \mathrm{kg}$ titanium dioxide as an indigestible marker. The diets had similar energy and protein content. Vitamins and minerals were included in all diets to meet the current requirement estimates of GfE [20]. Dry feed was given twice a day $(8.00 ; 16.00)$. The study period consisted of six-day adaptation to the diet and one-day collection of digesta. The digesta collected from each pig was mixed separately and representative samples were packed into the plastic bags. After the last sampling, fresh digesta was analysed microbiologically and the ileal $\mathrm{pH}$ was measured in each sample. The other fresh samples were frozen for chemical analysis (dry matter, ammonia, volatile fatty acids (VFA)). The rest of the collected material was frozen at $-70{ }^{\circ} \mathrm{C}$ and lyophilized. The dry matter and protein content, the amino acid composition of protein, and the titanium dioxide content in the digesta samples were determined. 
Table 3. The composition and calculated nutritional value of diets.

\begin{tabular}{cccccc}
\hline Components \% & SBM & RNL & FNL & RYL & FYL \\
\hline Soybean meal & 35.00 & - & - & - & - \\
Raw yellow /narrow-leaved lupine seeds & - & 51.38 & - & 42.00 & - \\
Fermented yellow /narrow-leaved lupine & - & - & 42.00 & - & 39.00 \\
seeds & & & & & 43.18 \\
Maize starch & 51.51 & 32.00 & 41.38 & 46.18 \\
Sugar & 10.00 & 10.00 & 10.00 & 10.00 & 10.00 \\
Soya oil & 0.00 & 3.00 & 1.00 & 3.00 & 1.00 \\
Limestone & 0.70 & 0.70 & 0.70 & 0.70 & 0.70 \\
Calcium phosphate & 1.70 & 1.80 & 2.00 & 1.80 & 2.00 \\
NaCl & 0.29 & 0.32 & 0.32 & 0.32 & 0.32 \\
Premix * & 0.50 & 0.50 & 0.50 & 0.50 & 0.50 \\
Titanium dioxide & 0.30 & 0.30 & 0.30 & 0.30 & 0.30 \\
\hline ME MJ/kg & 14.3 & 14.1 & 14.1 & 14.1 & 14.2 \\
Crude protein \% & 16.5 & 16.3 & 16.2 & 16.2 & 16.4 \\
Ca \% & 0.86 & 0.86 & 0.88 & 0.88 & 0.87 \\
P \% & 0.62 & 0.60 & 0.62 & 0.62 & 0.61 \\
Na \% & 0.13 & 0.13 & 0.13 & 0.13 & 0.13 \\
\hline
\end{tabular}

SBM-diet contained soybean meal as the sole component high in protein; RYL-diet contained raw yellow lupine seeds; FYL_-diet contained fermented yellow lupine seeds; RNL-diet contained raw narrow-leaved lupine seeds; FNL_-diet contained fermented narrow-leaved lupine seeds; ME—-metabolizable energy, was calculated in the program WinPasze, based on chemical composition of diets: EM, MJ $/ \mathrm{kg} \mathrm{DM}=0.0205 \times \mathrm{DP}+0.0398 \times \mathrm{DF}+$ $0.0173 \times S+0.0160 \times C+0.0147 \times$ DOM where: DP-digestible protein, DF-digestible fat, S-starch, C-sugars, DOM-digestible organic matter $(\mathrm{g} / \mathrm{kg} \mathrm{DM}) . ;{ }^{*}$ Premix-mineral and vitamin premix content (per $1 \mathrm{~kg}$ diet): Choline chloride 400 mg, Fe 100 mg, Cu 160 mg, Co 0.4 mg, Mn 40 mg, Zn 140 mg, J 0.8 mg, Se 0.2 mg, antioxidant (Butylated hydroxyanisole, Butylated hydroxytoluene); IU: 12,000 Vit. A; 1500 Vit. D $; 70$ mg Vit. E; 1.5 mg Vit. $\mathrm{K}_{3} ; 1.5 \mathrm{mg}$ Vit. $\mathrm{B}_{1} ; 4 \mathrm{mg}$ Vit. $\mathrm{B}_{2} ; 3 \mathrm{mg}$ Vit. $\mathrm{B}_{6} ; 25 \mu \mathrm{g}$ Vit. $\mathrm{B}_{12} ; 10 \mathrm{mg}$ Pantothenic Acid; $20 \mathrm{mg}$ Nicotinic acid; $2 \mathrm{mg}$ folic acid; $100 \mu \mathrm{g}$ Biotin; $0.9 \mathrm{~g} ; 0.6 \mathrm{~g}$; Calcium. Premix was produced by LNB.

The apparent ileal digestibility (AID) coefficients of protein and amino acids in SBM, raw and fermented lupine seeds were calculated with the following formula:

$\operatorname{AID}(\%)=100-100 \times(\%$ of marker in feed $/ \%$ of marker in faeces $) \times(\%$ nutrient in faeces $/ \%$ of nutrient in feed $)$

\subsection{Chemical and Microbial Analyses}

For chemical analysis all the samples were ground to pass through a $0.5-\mathrm{mm}$ sieve. Raw seeds, fermented products, and digesta samples $(n=5$, from different animals) were analysed in duplicate. The content of dry matter (DM), crude protein (CP), crude ash (CA), acid detergent fibre, and neutral detergent fibre was measured with methods 934.01, 976.05, 920.39, 942.05, and 973.18, respectively, according to the AOAC [21]. Lupine alkaloids were extracted from flour with trichloroacetic acid and methylene chloride (Sigma-Aldrich, Munich, Germany). The content of alkaloids was measured by means of gas chromatography (Shimadzu GC17A, Kyoto, Japan) with a capillary column (Phenomenex, Torrance, CA, USA). Raffinose family oligosaccharides were extracted and analysed by means of high-resolution gas chromatography, as described by Zalewski et al. [22]. The phytate content was measured according to the method described by Haug and Lantzsch [23]. The amino acid (AA) content was measured with an AAA-339 Mikrotechna amino acid analyser (Prague, Czech Republic), using ninhydrin for post-column derivatization. Before analysis, the samples were hydrolysed with $6 \mathrm{M} \mathrm{HCl}$ for $24 \mathrm{~h}$ at $110{ }^{\circ} \mathrm{C}$, according to procedure 994.12; AOAC [21]. The level of titanium dioxide (POCH, Gliwice, Poland) was measured with the method described by Short et al. [24]; the samples were prepared in accordance with the procedure described by Myers et al. [25]. Ten grams of the mixed ileal sample was added to $90 \mathrm{~mL}$ of ion-exchanged water and shaken.

The $\mathrm{pH}$ was measured in the liquid phase with a $\mathrm{pH}$ meter (model 301, Hanna Instruments, Vila do Conde, Portugal). Ammonia was analysed with the spectrometric method and Nessler reagent (POCh, Gliwice, Poland). The VFAs were analysed according to the 
procedure described by Barszcz et al. [26] with an HP 5890 Series II gas chromatograph (Hewlett Packard, Waldbronn, Germany) with a flame-ionization detector and a SupelcoNukol (Supelco, Bellafonte, KY, USA) fused silica capillary column $(30 \mathrm{~m} \times 0.25 \mathrm{~mm}$ i.d.; $0.25 \mathrm{~mm}$ ). Helium was the carrier gas.

Samples for bacteriological analysis were prepared by adding $27 \mathrm{~mL}$ of buffered peptone water (Oxoid) to $3 \mathrm{~g}$ of samples and homogenizing for $30 \mathrm{~s}$ in a laboratory stomacher. Microbial counts were measured with a decimal dilution series of the homogenized samples. The total bacteria count and lactic acid bacteria count were measured with plate standard methods, using plate count agar (PCA) and MRS broth (Oxoid), respectively, after 72 -h incubation at $30^{\circ} \mathrm{C}$. The yeast content was calculated with pre-supplemented DRBC (Oxoid) after incubation at $25^{\circ} \mathrm{C}$ for 3 to 5 days. The count of coliform bacteria was measured with Violet Red Bile lactose agar (Oxid, Hampshire, UK) after 24-h incubation at $30^{\circ} \mathrm{C}$.

\subsection{Statistical Analysis}

The SAS Enterprise Guide 5.1 (USA) program was used for statistical analysis. The data were analysed with one-way (feed effect) and two-way (variety effect, fermentation effect) analysis of variance ANOVA. The differences between the means were compared with Duncan's test at $p<0.05$.

\section{Results}

The AID coefficients of protein and amino acids (Table 4) were different in almost all components under analysis, except for glutamine, proline, glycine, phenylalanine, and lysine. The SBM and FNL were characterized by significantly higher $(p<0.05)$ AID coefficients of crude protein, asparagine, threonine, serine, isoleucine, leucine, histidine ant tyrosine than the other variants. The digesta of the pig from the SBM variant had lower AID of cysteine than in both lupine groups, but the AID coefficients of alanine and methionine were significantly higher $(p<0.05)$ than in the other components. Fermentation significantly improved the digestibility coefficients of crude protein, asparagine, threonine, tyrosine, histidine, and arginine, whereas narrow-leaved lupine was characterized by higher apparent ileal digestibility coefficients of asparagine, threonine, serine, alanine, valine, isoleucine, and arginine than yellow lupine. There was interaction between the seeds and fermentation process in the AID of threonine, serine, leucine, and histidine.

Table 4. The apparent ileal digestibility coefficients of protein and amino acids in raw and fermented lupine seeds and soybean meal $(n=5)$.

\begin{tabular}{|c|c|c|c|c|c|c|c|c|c|c|c|c|c|c|}
\hline \multirow{2}{*}{ Item \% } & \multicolumn{7}{|c|}{ Component Effect } & \multicolumn{3}{|c|}{$\begin{array}{l}\text { Fermentation Effect } \\
\text { (F) }\end{array}$} & \multicolumn{3}{|c|}{ Seeds Effect (S) } & \multirow{2}{*}{$\begin{array}{c}\begin{array}{c}\text { Interaction } \\
(\mathbf{F} \times \mathbf{S})\end{array} \\
\mathbf{P}\end{array}$} \\
\hline & SBM & RNL & FNL & RYL & FYL & $\mathbf{P}$ & SEM & NO & YES & $\mathbf{P}$ & NL & YL & $\mathbf{P}$ & \\
\hline $\mathrm{CP}$ & $74.88^{a}$ & $68.38^{b}$ & $73.47^{\mathrm{a}}$ & $69.30^{b}$ & $70.20^{b}$ & 0.011 & 1.47 & 69.29 & 71.38 & 0.041 & 70.92 & 69.75 & 0.214 & 0.226 \\
\hline Lysine & 77.80 & 71.29 & 75.33 & 71.64 & 71.44 & 0.116 & 0.36 & 71.48 & 73.60 & 0.371 & 73.54 & 71.55 & 0.408 & 0.325 \\
\hline Methionine & $84.59^{a}$ & $63.61^{\mathrm{b}}$ & $62.44^{b}$ & $64.72^{b}$ & $56.76^{\mathrm{b}}$ & 0.001 & 2.26 & 63.78 & 59.91 & 0.169 & 62.51 & 61.18 & 0.535 & 0.187 \\
\hline Threonine & $66.65^{\mathrm{a}}$ & $52.48^{b}$ & $66.08^{a}$ & $48.47^{\mathrm{b}}$ & $52.84^{b}$ & 0.001 & 1.84 & 50.25 & 60.20 & 0.005 & 60.03 & 50.41 & 0.001 & 0.038 \\
\hline Isoleucine & $76.59^{a}$ & $73.61^{a b}$ & $75.38^{a}$ & $69.26^{b c}$ & $65.92^{c}$ & 0.001 & 1.05 & 71.19 & 71.18 & 0.633 & 74.60 & 67.77 & 0.001 & 0.133 \\
\hline Leucine & $73.02^{a}$ & $66.66^{\mathrm{b}}$ & $72.56^{\mathrm{a}}$ & $69.81^{a b}$ & $66.10^{\mathrm{b}}$ & 0.010 & 0.85 & 68.41 & 69.69 & 0.489 & 69.94 & 68.16 & 0.299 & 0.007 \\
\hline Valine & $71.83^{a}$ & $63.17^{a c}$ & $68.19^{a b}$ & $58.81^{\mathrm{cd}}$ & $56.06^{d}$ & 0.001 & 1.44 & 60.75 & 62.80 & 0.556 & 65.96 & 57.59 & 0.001 & 0.058 \\
\hline Histidine & $69.87^{a}$ & $62.56^{b}$ & $69.22^{\mathrm{a}}$ & $56.41^{\mathrm{b}}$ & $61.79^{\mathrm{b}}$ & 0.001 & 1.34 & 59.40 & 66.26 & 0.007 & 63.53 & 62.13 & 0.767 & 0.014 \\
\hline Arginine & $83.57^{b c}$ & $85.26^{b}$ & $89.22^{\mathrm{a}}$ & 80.46 & $83.68^{\mathrm{bc}}$ & 0.002 & 0.85 & 82.60 & 86.76 & 0.024 & 87.46 & 81.89 & 0.003 & 0.798 \\
\hline Cystine & $76.03^{b}$ & $82.10^{a}$ & $80.01^{a b}$ & $85.87^{\mathrm{a}}$ & $82.63^{a}$ & 0.016 & 0.92 & 83.64 & 81.18 & 0.232 & 80.94 & 83.87 & 0.142 & 0.966 \\
\hline Phenylalanine & 76.81 & 68.26 & 74.66 & 69.48 & 68.08 & 0.084 & 1.27 & 68.93 & 71.73 & 0.374 & 71.81 & 68.86 & 0.342 & 0.174 \\
\hline Asparagine & $72.83^{a}$ & $65.23^{\mathrm{b}}$ & $72.12^{a}$ & $59.90^{\mathrm{b}}$ & $62.36^{\mathrm{b}}$ & 0.001 & 1.37 & 62.27 & 67.78 & 0.036 & 69.06 & 60.99 & 0.002 & 0.289 \\
\hline Serine & $73.62^{a}$ & $67.67^{b}$ & $75.54^{a}$ & $67.81^{\mathrm{b}}$ & $66.61^{b}$ & 0.002 & 1.03 & 67.75 & 71.57 & 0.070 & 72.05 & 67.28 & 0.022 & 0.019 \\
\hline Tyrosine & $71.27^{\mathrm{a}}$ & $59.12^{c}$ & $68.48^{a b}$ & $55.35^{c}$ & $61.43^{b c}$ & 0.002 & 1.65 & 57.03 & 65.35 & 0.012 & 64.32 & 58.05 & 0.064 & 0.551 \\
\hline Proline & 59.89 & 62.97 & 60.82 & 55.31 & 52.34 & 0.794 & 2.69 & 59.14 & 59.58 & 0.729 & 61.89 & 53.83 & 0.291 & 0.956 \\
\hline Glutamine & 83.00 & 82.06 & 56.28 & 80.61 & 82.72 & 0.114 & 0.74 & 81.25 & 84.70 & 0.073 & 84.40 & 81.55 & 0.147 & 0.528 \\
\hline Glycine & 59.05 & 53.45 & 57.24 & 49.07 & 51.83 & 0.487 & 1.92 & 51.01 & 54.83 & 0.496 & 55.55 & 50.29 & 0.314 & 0.914 \\
\hline Alanine & $68.71^{\mathrm{a}}$ & $58.72 \mathrm{bc}$ & $60.81^{b}$ & $56.22 \mathrm{bc}$ & $50.81^{\mathrm{c}}$ & 0.002 & 1.60 & 57.33 & 56.36 & 0.548 & 59.88 & 53.81 & 0.036 & 0.186 \\
\hline
\end{tabular}

a-d_data significantly different among groups at $p<0.05 ; p$-values $<0.05$ were signed in bold; SBM-diet contained soybean meal as the sole component high in protein; RYL_diet contained raw yellow lupine seeds; FYL_diet contained fermented yellow lupine seeds; RNL_diet contained raw narrow-leaved lupine seeds; FNL_diet contained fermented narrow-leaved lupine seeds. 
The ileal digesta of the pigs fed with FYL (Table 5) contained more bacteria $(p<0.05)$ than in the other variants. The yeast count was significantly higher $(p<0.05)$ in the FNL than in the SBM and RYL digesta. The yeast count in the FYL variant was also significantly higher than in the RYL digesta. The highest count of moulds was found in the digesta of the pigs from the FNL and RYL variants $(p<0.05)$, whereas the FYL, SBM and RNL digesta had almost no moulds. There were no differences in the LAB and Enterobacteriaceae content $(p>0.05)$. Fermentation significantly increased the counts of total bacteria and yeast, whereas the ileal digesta of the pigs fed with narrow-leaved lupine products had higher LAB and moulds counts but lower total bacteria count. There was interaction between the counts of total bacteria, moulds, and yeast.

Table 5. The microflora content in the ileal digesta $(n=5)$.

\begin{tabular}{|c|c|c|c|c|c|c|c|c|c|c|c|c|c|c|}
\hline \multirow{2}{*}{$\log _{10}$ CFU/g } & \multicolumn{7}{|c|}{ Component Effect } & \multicolumn{3}{|c|}{$\begin{array}{l}\text { Fermentation Effect } \\
\text { (F) }\end{array}$} & \multicolumn{3}{|c|}{$\begin{array}{l}\text { Seeds Effect } \\
\text { (S) }\end{array}$} & \multirow{2}{*}{$\begin{array}{c}\begin{array}{c}\text { Interaction } \\
(\mathbf{F} \times \mathbf{S})\end{array} \\
\mathbf{P}\end{array}$} \\
\hline & SBM & RNL & FNL & RYL & FYL & $\mathbf{P}$ & SEM & NO & YES & $\mathbf{P}$ & NL & YL & $\mathbf{P}$ & \\
\hline Total bacteria & $8.12^{b}$ & $8.43^{b}$ & $8.47^{\mathrm{b}}$ & $8.26^{b}$ & $10.99^{\mathrm{a}}$ & 0.001 & 0.259 & 8.35 & 9.87 & 0.001 & 8.45 & 9.78 & 0.001 & 0.001 \\
\hline Yeast & $4.60^{b c}$ & $5.04^{\mathrm{abc}}$ & $6.14^{\mathrm{a}}$ & $4.32^{c}$ & $5.72^{\mathrm{ab}}$ & 0.042 & 0.224 & 4.68 & 5.91 & 0.023 & 5.59 & 5.10 & 0.262 & 0.749 \\
\hline Moulds & $0.54^{\mathrm{b}}$ & $0.85^{b}$ & $4.97^{\mathrm{a}}$ & $3.56^{a}$ & $0.00^{b}$ & 0.001 & 0.446 & 2.20 & 2.21 & 0.994 & 2.91 & 1.58 & 0.022 & 0.001 \\
\hline LAB & 8.20 & 8.12 & 8.52 & 8.55 & 7.47 & 0.204 & 0.163 & 8.33 & 7.93 & 0.319 & 8.32 & 7.95 & 0.359 & 0.041 \\
\hline Enterobacteriaceae & 6.95 & 7.51 & 7.89 & 7.52 & 6.54 & 0.140 & 0.187 & 7.52 & 7.14 & 0.435 & 7.70 & 6.98 & 0.092 & 0.089 \\
\hline
\end{tabular}

${ }^{\mathrm{a}-\mathrm{c}}$ —data significantly different among groups at $p<0.05 ; p$-values $<0.05$ were signed in bold; SBM—diet contained soybean meal as the sole component high in protein; RYL—diet contained raw yellow lupine seeds; FYL—diet contained fermented yellow lupine seeds; RNL—diet contained raw narrow-leaved lupine seeds; FNL—diet contained fermented narrow-leaved lupine seeds.

The ileal digesta of the pigs from all variants contained different $(p<0.05)$ amounts of dry matter, ammonia, and volatile fatty acids (except propionate and valerate) (Table 6). The dry matter content in the ileal digesta in the RNL, FNL, RYL and FYL variants was significantly higher than in the SBM. The RNL digesta was characterized by higher dry matter content than the FNL. The lowest $\mathrm{pH}$ was noted in the ileal digesta of the pig fed with RYL $(p<0.05)$. There was significantly higher $\mathrm{pH}$ in the digesta of both NL variants. The ammonia content in the ileal digesta of the SBM variant was the lowest $(p<0.05)$, whereas in the RYL and RNL variants it was significantly higher $(p<0.05)$ than in other variants. The lowest VFA content in the ileal digesta was found in the SBM variant; the highest-in the FNL and RYL variants. The acetate content in the digesta of the pig fed with SBM was significantly higher $(p<0.05)$ than in the RNL and FYL variants. The isobutyrate and butyrate content in the ileal digesta of the FYL variant were higher than in the SBM, RNL, and FNL variants, whereas the isovalerate content in the FNL and FYL digesta was higher than in the other variants. Fermentation significantly $(p<0.05)$ decreased the dry matter and ammonia content in the digesta. Moreover, the digesta of the pigs fed with fermented seeds had higher $\mathrm{pH}(p<0.05)$ and isobutyrate and isovalerate contents. The ileal digesta of the pigs fed yellow lupine seeds had lower $\mathrm{pH}$ but higher isobutyrate and butyrate contents $(p<0.05)$. There was no interaction between the seeds and fermentation. 
Table 6. Dry matter, $\mathrm{pH}$, ammonia content and volatile fatty acids content and profile in ileal digesta of pigs $(n=5)$.

\begin{tabular}{|c|c|c|c|c|c|c|c|c|c|c|c|c|c|c|}
\hline \multirow{2}{*}{ Item } & \multicolumn{7}{|c|}{ Component Effect } & \multicolumn{3}{|c|}{$\begin{array}{l}\text { Fermentation Effect } \\
\text { (F) }\end{array}$} & \multicolumn{3}{|c|}{$\begin{array}{l}\text { Seeds Effect } \\
\text { (S) }\end{array}$} & \multirow{2}{*}{$\begin{array}{c}\begin{array}{c}\text { Interactionb } \\
(\mathbf{F} \times \mathbf{S})\end{array} \\
\mathbf{P}\end{array}$} \\
\hline & SBM & RNL & FNL & RYL & FYL & $\mathbf{P}$ & SEM & NO & YES & $\mathbf{P}$ & NL & YL & $\mathbf{P}$ & \\
\hline Dry mater, \% & $7.95^{c}$ & $12.03^{a}$ & $10.84^{b}$ & $11.77^{a b}$ & $11.24^{a b}$ & 0.001 & 0.16 & 11.92 & 11.04 & 0.012 & 11.46 & 11.50 & 0.898 & 0.884 \\
\hline $\mathrm{pH}$ & $6.54^{\mathrm{b}}$ & $6.76^{\mathrm{a}}$ & $6.72^{\mathrm{a}}$ & $6.05^{c}$ & $6.52^{b}$ & 0.001 & 0.02 & 6.45 & 6.62 & 0.010 & 6.74 & 6.33 & 0.001 & 0.111 \\
\hline $\begin{array}{l}\text { Ammonia, } \\
\mathrm{mmol} / \mathrm{g}\end{array}$ & $15.66^{c}$ & $23.85^{\mathrm{a}}$ & $21.67^{b}$ & $24.89^{\text {a }}$ & $20.15^{b}$ & 0.001 & 0.30 & 24.37 & 20.91 & 0.001 & 22.76 & 22.52 & 0.738 & 0.652 \\
\hline VFA mmol/g & $19.57^{c}$ & $40.11^{b}$ & $50.71^{a}$ & $50.85^{a}$ & $36.86^{b}$ & 0.001 & 1.45 & 45.48 & 43.78 & 0.682 & 44.41 & 43.86 & 0.707 & 0.254 \\
\hline Acetate, $\%$ VFA & $81.38^{a}$ & $74.12^{\mathrm{b}}$ & $75.81^{a b}$ & $75.47^{\mathrm{ab}}$ & $71.50^{\mathrm{b}}$ & 0.029 & 0.94 & 74.80 & 73.65 & 0.604 & 74.96 & 73.49 & 0.505 & 0.321 \\
\hline $\begin{array}{l}\text { Propionate \% } \\
\text { VFA }\end{array}$ & 13.89 & 19.66 & 17.63 & 15.74 & 18.97 & 0.107 & 0.74 & 17.70 & 18.30 & 0.725 & 18.64 & 17.35 & 0.454 & 0.188 \\
\hline $\begin{array}{c}\text { Isobutyrate, } \% \\
\text { VFA }\end{array}$ & $0.23^{c}$ & $0.21^{\mathrm{c}}$ & $0.30^{b c}$ & $0.34^{a b}$ & $0.40^{\mathrm{a}}$ & 0.001 & 0.01 & 0.27 & 0.35 & 0.011 & 0.25 & 0.37 & 0.001 & 0.401 \\
\hline Butyrate, \% VFA & $3.70^{c}$ & $4.27^{b c}$ & $4.66^{\mathrm{bc}}$ & $6.35^{\mathrm{ab}}$ & $7.13^{\mathrm{a}}$ & 0.018 & 0.366 & 5.31 & 5.89 & 0.505 & 4.46 & 6.74 & 0.011 & 0.314 \\
\hline $\begin{array}{c}\text { Isovalerate, } \% \\
\text { VFA }\end{array}$ & $0.19^{c}$ & $0.36^{\mathrm{b}}$ & $0.52^{\mathrm{a}}$ & $0.34^{\mathrm{b}}$ & $0.55^{\mathrm{a}}$ & 0.001 & 0.02 & 0.31 & 0.54 & 0.001 & 0.44 & 0.45 & 0.898 & 0.228 \\
\hline Valerate, $\%$ VFA & 0.62 & 1.38 & 1.08 & 1.76 & 1.45 & 0.114 & 0.14 & 1.57 & 1.26 & 0.357 & 1.23 & 1.60 & 0.257 & 0.455 \\
\hline
\end{tabular}

a-c_-data significantly different among groups at $p<0.05 ; p$-values $<0.05$ were signed in bold; SBM-diet contained soybean meal as the sole component high in protein; RYL_diet contained raw yellow lupine seeds; FYL_diet contained fermented yellow lupine seeds; RNL-diet contained raw narrow-leaved lupine seeds; FNL_diet contained fermented narrow-leaved lupine seeds.

\section{Discussion}

The yellow and narrow-leaved lupine seeds were fermented by Candida utilis. This strain was selected in this study as it proved to be the most efficient in earlier experiments on lupine seed fermentation with different yeast strains $[15,27]$. The fermentation of the seeds of both lupine species affected their chemical composition. It increased the protein, lysine, cystine, and threonine content but not the methionine content. Fermentation by Candida utilis also reduced the ADF, NDF, and phytate-P, but the content of alkaloids increased. This is consistent with the observations made by Kasprowicz-Potocka et al. [27], who concluded that lupine alkaloids were resistant to yeast fermentation. After the fermentation no RFO was found in the seeds, which was in line with the observations made by other authors $[6,17,27-29]$. It is clear that an increase in the crude protein content results from a decrease in the content of nonstructural and structural carbohydrates in the biomass and from the growth of microorganisms. Fermented products were characterized by acidic $\mathrm{pH}$ and higher content of yeast and bacteria. Other authors also observed a higher level of lactic acid bacteria, yeast, and total bacteria after the fermentation of legumes $[17,30]$.

The experimental diets contained less fermented than raw seeds, which was reflected by the higher protein content in the fermented seeds, but the nutritional value of all the diets was similar. The digestibility of nutrients is an important factor determining the use of feed and it is indirectly related to the protein quality and the ANF level [31]. According to the data in scientific publications, the digestibility of SBM is slightly higher than that of lupine meal, which mostly results from the presence of anti-nutrients in lupine seeds [32]. In the current study, the AID of protein and amino acids in SBM was similar to the values reported by Kong et al. [33] and by Upadhaya and Kim [34]. The AID coefficient of fermented narrow-leaved lupine protein did not differ from that of SBM but in raw narrow-leaved as well as raw and fermented yellow lupine seeds the digestibility of protein was significantly lower. In a study on rats the apparent protein digestibility of fermented lupine seeds was about $2 \%$ greater than that of unprocessed seeds [27]. Zaworska-Zakrzewska et al. [17] conducted a study on pigs and found that the bacterial fermentation of narrow-leaved lupine seeds (var. Neptun) increased the digestibility of crude protein by $11 \%$. In this study, it was only $1.2 \%$ and $7 \%$ for yellow lupine and narrowleaved lupine, respectively. In the current research, fermentation significantly improved the digestibility of asparagine, threonine, tyrosine, histidine, and arginine, whereas Zaworska et al. [6] noted that fermented narrow-leaved lupine seeds had significantly higher AID coefficients for arginine, isoleucine, and cysteine than row seeds. The differences may have been caused by the higher content of protein in the fermented seeds and by the higher level of antinutrients such as alkaloids, RFOs, and phytate in the raw lupine seeds, especially yellow ones. Antinutrients inhibit the activity of protolithic enzymes and thus reduce 
the digestibility of feed [31,35]. Upadhaya and Kim [34] fermented SBM with bacteria and yeasts and observed significant improvement of pigs' intestinal digestibility. Kim et al. [36] found that SBM fermented with Bacillus subtilis significantly improved the AID of phenylalanine, isoleucine, and valine. In the present study, narrow-leaved lupine seeds were characterized by higher digestibility coefficients of protein and amino acids than yellow lupine seeds. A similar trend was observed in the study on rats [27]. The differences in the AID coefficients for the protein and amino acids in SBM and in lupine seeds may have been caused by the conditions and methods of conducting research on animals (different breeds, indices, methodologies). They may also depend on the chemical characteristics of raw materials (cultivar, the level of nutrients, ANF content) and conditions of fermentation (microorganisms, time, humidity, temperature).

The composition of a diet may affect not only the digestibility of nutrients but it may also influence the microflora. In the current research the fermented products contained more lactic acid bacteria and yeast than the raw seeds due to the microbial activity during processes. At the same time the $\mathrm{pH}$ in the fermented products was lower. The ileal digesta of the pigs consuming fermented products also had higher levels of total bacteria and yeast, but fermentation did not affect the content of moulds and enterobacteria. By contrast, the studies by Zaworska et al. [6] and Zaworska-Zakrzewska et al. [17] showed that fermented narrow-leaved lupine seeds did not affect the ecology of pigs' gastrointestinal tract. There were also differences between cultivars, with higher counts of moulds and LAB in the digesta of the pigs fed with narrow-leaved lupine seeds in the diet. This effect may have been caused by the higher content of these microorganisms in the feed components as well as the higher content of narrow-leaved products in the diet. The characteristic $\mathrm{pH}$ value of about 6-7 in the pig's ileum does not favour the development of lactic acid bacteria, but some other bacteria and yeast can grow, as was evidenced by this study. Yeast development is the most effective at $\mathrm{pH}$ of $4.5-6.5$, but the activity connected with prebiotic functions generally takes place in the distal ileal part of the digestive tract. Moreover, other authors found that the supplementation of feed with fermented components improved the regulation of pigs and rats' intestinal microflora [37,38]. Fermented components in the diet increased $\mathrm{pH}$ in the ileum, but decreased the dry matter level and ammonia content. It pointed to rather poor microbial activity in the ileal part of the digestive tract, which is in line with the low content of total volatile fatty acids. The protein structure in the fermented products was partly degraded by bacteria. The degradation may have made them more digestible, as was proved by the higher AID of protein and some amino acids. On the other hand, the lower content of dry matter, ammonia, and fatty acids in the soybean meal may have been caused by the lower count of microorganisms in the digesta. It is likely that the ileal digesta of the pigs fed with lupine seed meals had higher concentrations of short-chain fatty acids than the digesta of the pig fed with soybean meal due to the higher total content of lupine NSP and lupine oligosaccharides in the raw seeds. In the current study there were differences between the varieties. The yellow lupine products reduced the $\mathrm{pH}$ of the digesta by 0.4 and increased the isobutyrate and butyrate levels. The main end products formed during the fermentation of nondigestible carbohydrates are acetic, propionic, and butyric acids [39], as evidenced by the results of this study. Only the isovalerate and isobutyrate content was significantly higher in the ileal digesta of the pigs consuming fermented feed, but generally the amount of these two acids was very low. In the study by Zaworska et al. [6] the digesta of the pigs fed with raw narrow-leaved lupine seeds had significantly higher concentrations of total SCFA than the raw seeds.

\section{Conclusions}

To sum up, fermentation reduced the content of antinutritional substances in the lupine seeds, which increased the content of protein and some amino acids. Moreover, it reduced the $\mathrm{pH}$ of the product and increased the counts of yeast and lactic acid bacteria. The chemical and biological changes in the seeds caused by fermentation increased the counts of bacteria and yeast in the digesta and thus improved the digestibility coefficients 
of protein and some amino acids as threonine, arginine, histidine and tyrosine in the ileum of pigs. Generally, the fermentation of narrow-leaved and yellow lupine seeds led to similar results, but fermented narrow-leaved seeds seemed to be more convenient for the pigs. Using of Candida utilis yeast for fermentation of narrow-leafed lupine seeds could be a good solution for improving of feed quality and its nutritional value, but it could increase the cost of the nutrition, so more research should be provided including economic analysis of feeding.

Author Contributions: Conceptualization, M.K.-P. and A.Z.-Z.; Methodology, M.K.-P. and M.T.; Software, A.Z.-Z.; Validation, A.Z.-Z.; Formal Analysis, M.K.-P., A.Z.-Z. and M.T.; Investigation, M.K.-P. and A.Z.-Z.; Resources, A.F.; Data Curation, M.K.-P. and A.Z.-Z.; Writing-Original Draft Preparation, A.Z.-Z. and M.K.-P.; Writing-Review \& Editing, A.Z.-Z. and M.K.-P.; Visualization, M.K.-P.; Supervision, A.F.; Project Administration, A.F; Funding Acquisition, A.F. and M.K.-P. All authors have read and agreed to the published version of the manuscript.

Funding: The study was supported by the National Science Centre No. 2011/01/B/NZ9/00232.

Institutional Review Board Statement: The study was conducted according to the guidelines of the EU Directive 2010/63/EU, and approved by the Ethics Committee of Poznan University of Life Sciences $(43 / 2011 ; 5$ November 2011).

Conflicts of Interest: The authors declare no conflict of interest. The funders had no role in the design of the study; in the collection, analyses, or interpretation of data; in the writing of the manuscript, or in the decision to publish the results.

\section{References}

1. Olukomaiya, O.; Fernando, C.; Mereddy, R.; Li, X.; Sultanbawa, Y. Solid-state fermented plant protein sources in the diets of broiler chickens: A review. Anim. Nutr. 2019, 5, 319-330. [CrossRef]

2. Zentek, J.; Boroojeni, F.G. (Bio) Technological processing of poultry and pig feed: Impact on the composition, digestibility, anti-nutritional factors and hygiene. Anim. Feed Sci. Technol. 2020, 11, 45-76. [CrossRef]

3. Wang, C.; Wei, S.; Xu, B.; Hao, L.; Su, W.; Jin, M.; Wang, Y. Bacillus subtilis and Enterococcus faecium co-fermented feed regulates lactating sow's performance, immune status and gut microbiota. Microb. Biotechnol. 2021, 14, 614-627. [CrossRef] [PubMed]

4. Wang, C.; Shi, C.; Zhang, Y.; Song, D.; Lu, Z.; Wang, Y. Microbiota in fermented feed and swine gut. Appl. Microbiol. Biotechnol. 2018, 102, 2941-2948. [CrossRef] [PubMed]

5. Lin, K.-H.; Yu-Hsiang, Y. Evaluation of Bacillus licheniformis-fermented feed additive as an antibiotic substitute: Effect on the growth performance, diarrhea incidence, and cecal microbiota in weaning piglets. Animal 2020, 10, 1649. [CrossRef] [PubMed]

6. Zaworska, A.; Frankiewicz, A.; Kasprowicz-Potocka, M. The influence of narrow-leafed lupin seed fermentation on their chemical composition and ileal digestibility and microbiota in growing pigs. Archiv. Anim. Nutr. 2017, 71, 285-296. [CrossRef]

7. Kasprowicz-Potocka, M.; Borowczyk, P.; Zaworska, A.; Nowak, W.; Frankiewicz, A.; Gulewicz, P. The effect of dry yeast fermentation on chemical composition and protein characteristics of blue lupin seeds. Food Technol. Biotechnol. 2016, 54, 360-366. [CrossRef] [PubMed]

8. Sugiharto, S.; Ranjitkar, S. Recent advances in fermented feeds towards improved broiler chicken performance, gastrointestinal tract microecology and immune responses: A review. Anim. Nutr. 2019, 5, 1-10. [CrossRef]

9. Qiu, Y.; Li, K.; Zhao, X.; Liu, S.; Wang, L.; Yang, X.; Jiang, Z. Fermented Feed Modulates Meat Quality and Promotes the Growth of Longissimus Thoracis of Late-Finishing Pigs. Animal 2020, 10, 1682. [CrossRef] [PubMed]

10. Hanczakowska, E.; Swiatkiewicz, M. Legume seeds and rapeseed press cake as replacers of soybean meal in feed for fattening pigs. Ann. Anim. Sci. 2014, 14, 921. [CrossRef]

11. Kaczmarek, S.A.; Kasprowicz-Potocka, M.; Hejdysz, M.; Mikuła, R.; Rutkowski, A. The nutritional value of narrow-leafed lupin (Lupinus angustifolius) for broilers. J. Anim. Feed Sci. 2014, 23, 160-166. [CrossRef]

12. Sedláková, K.; Straková, E.; Suchý, P.; Krejcarová, J.; Herzig, I. Lupin as a perspective protein plant for animal and human nutrition-a review. Acta Vet. Brno 2016, 85, 165-175. [CrossRef]

13. Degola, L.; Jonkus, D. The influence of dietary inclusion of peas, faba bean and lupin as a replacement for soybean meal on pig performance and carcass traits. Agron. Res. 2018, 16, 389-397.

14. Kasprowicz-Potocka, M.; Zaworska, A.; Kaczmarek, S.A.; Rutkowski, A. The nutritional value of narrow-leafed lupin (Lupinus angustifolius) for fattening pigs. Arch. Anim. Nutr. 2016, 70, 209-223. [CrossRef]

15. Kasprowicz-Potocka, M.; Zaworska, A.; Gulewicz, P.; Nowak, P.; Frankiewicz, A. The effect of fermentation of high alkaloid seeds of Lupinus angustifolius var. Karo by Saccharomyces cerevisieae, Kluyveromyces lactis and Candida utilis on the chemical and microbial composition of products. J. Food Proc. Preserv. 2018, 42, e13487. [CrossRef] 
16. Musco, N.; Cutrignelli, M.I.; Calabrò, S.; Tudisco, R.; Infascelli, F.; Grazioli, R.; Chiofalo, B. Comparison of nutritional and antinutritional traits among different species (Lupinus albus L., Lupinus luteus L., Lupinus angustifolius L.) and varieties of lupin seeds. J. Anim. Physiol. Anim. Nutr. 2017, 101, 1227-1241. [CrossRef]

17. Zaworska-Zakrzewska, A.; Kasprowicz-Potocka, M.; Mikuła, R.; Taciak, M.; Pruszyńska-Oszmałek, E.; Frankiewicz, A. Growth Performance, Gut Environment and Physiology of the Gastrointestinal Tract in Weaned Piglets Fed a Diet Supplemented with Raw and Fermented Narrow-Leafed Lupin Seeds. Animal 2020, 10, 2084. [CrossRef]

18. Zaworska-Zakrzewska, A.; Kasprowicz-Potocka, M.; Nowak, P.; Wiśniewska, Z.; Rutkowski, A. The nutritional value of yellow lupin (Lupinus luteus) for growing pigs. J. Agric. Sci. Technol. A 2019, 9, 351-363. [CrossRef]

19. van Leeuwen, P.; van Kleef, D.J.; van Kempen, G.J.M.; Huisman, J.; Verstegen, M.W.A. The Post Valve T-Caecum cannulation technique in pigs applicated to determine the digestibility of amino acid in maize, groundnut and sunflower meal. J. Anim. Physiol. Anim. Nutr. 1991, 65, 183-193. [CrossRef]

20. GfE [Gesellschaft für Ernährungsphysiologie]. Empfehlungen zur Energie- und Nährstoffversorgung von Schweinen; DLG-Verlag: Frankfurt am Main, Germany, 2006; Volume 10.

21. AOAC. Agricultural Chemicals. Official Methods of Analysis, 18th ed.; Association of Official Analytical Chemists: Gaithersburg, MD, USA, 2007.

22. Zalewski, K.; Lahuta, L.B.; Horbowicz, M. The effect of soil drought on the composition of carbohydrates in yellow lupin seeds and triticale kernels. Acta Physiol. Plant. 2001, 23, 73-78. [CrossRef]

23. Haug, W.; Lantzsch, H.J. Sensitive method for the rapid determination of phytate in cereals and cereal products. J. Sci. Food Agric. 1983, 34, 1423-1426. [CrossRef]

24. Short, F.J.; Gorton, P.; Wiseman, J.; Boorman, K.N. Determination of Titanium Dioxide Added as an Inert Marker in Chicken Digestibility Studies. Anim. Feed Sci. Technol. 1996, 59, 215-221. [CrossRef]

25. Myers, W.D.; Ludden, P.A.; Nayigihugu, V.; Hess, B.W. Technical note: A procedure for the preparation and quantitative analy sis of samples for titanium dioxide. J. Anim. Sci. 2004, 82, 179-183. [CrossRef] [PubMed]

26. Barszcz, M.; Taciak, M.; Skomiał, J. A dose-response effects of tannic acid and protein on growth performance, caecal fermentation, colon morphology, and $\beta$-glucuronidase activity of rats. J. Anim. Feed Sci. 2011, 20, 613-625. [CrossRef]

27. Kasprowicz-Potocka, M.; Zaworska, A.; Frankiewicz, A.; Nowak, W.; Gulewicz, P.; Zduńczyk, Z.; Juśkiewicz, J. The nutritional value and physiological properties of diets with raw and Candida utilis-fermented lupin seeds in rats. Food Technol. Biotechnol. 2015, 53, 286-297. [CrossRef]

28. Feng, J.; Liu, X.; Xu, Z.R.; Lu, Y.P.; Liu, Y.Y. Effect of fermented soybean meal on intestinal morphology and digestive enzyme activities in weaned piglets. Dig. Dis. Sci. 2007, 2, 1845-1850. [CrossRef]

29. Yabaya, A.; Akinyanju, J.A.; Jatou, E.D. Yeast enrichment of soybean cake. World J. Dairy Food Sci. 2009, 4, 141-144.

30. Wakil, S.M.; Onilude, A.A. Microbiological and chemical changes during production of malted and fermented Cereal-Legume weaning foods. Adv. Food Sci. 2009, 31, 139-145.

31. Sauer, W.C.; Fan, M.Z.; Mosenthin, R.; Drochner, W. Methods for measuring ileal amino acid digestibility in pigs. In Farm Animal Metabolism and Nutrition; CABI Publishing: Wallingford, UK, 2000; pp. 279-306.

32. Grela, E.G.; Skomiał, J. Recommended Allowances and Nutritive Value of Feedstuffs for Swine; The Kielanowsk iInstitute of Animal Physiology and Nutrition, Polish Academy of Sciences: Jabłonna, Poland, 2020. (In Polish)

33. Kong, C.; Kang, H.G.; Kim, B.G.; Kim, K.H. Ileal digestibility of amino acids in meat meal and soybean meal fed to growing pigs. Asian Australas. J. Anim. Sci. 2014, 7, 990-995. [CrossRef]

34. Upadhaya, S.D.; Kim, I.H. Ileal digestibility of nutrients and amino acids in unfermented, fermented soybean meal and canola meal for weaning pigs. Anim. Sci. J. 2014, 86, 408-414. [CrossRef]

35. Stanek, M.; Rotkiewicz, T.; Sobotka, W.; Bogusz, J.; Otrocka-Domagała, I.; Rotkiewicz, A. The effect of alkaloids presents in blue lupin (Lupinus angustifolius) seeds on the growth rate, selected biochemical blood indicators and histopathological changes in the liver of rats. Acta Vet. Brno 2015, 84, 55-62. [CrossRef]

36. Kim, D.H.; Heo, P.S.; Jang, J.C.; Jin, S.S.; Hong, J.S.; Kim, J.J. Effect of different soybean meal type on ileal digestibility of amino acid in weaning pigs. J. Anim. Sci. Technol. 2015, 57, 11. [CrossRef]

37. Kim, J.C.; Mullan, B.P.; Nicholls, R.R.; Pluske, J.R. Effect of Australian sweet lupin (Lupinus angustifolius L.) inclusion levels and enzyme supplementation on the performance and meat quality of grower/finisher pigs. Anim. Prod. Sci. 2011, 51, 37-43. [CrossRef]

38. Xu, B.; Li, Z.; Wang, C.; Fu, J.; Zhang, Y.; Wang, Y.; Lu, Z. Effects of fermented feed supplementation on pig growth performance: A meta-analysis. Anim. Feed Sci. Technol. 2020, 259, 114315. [CrossRef]

39. Topping, D.L.; Clifton, P.M. Short-chain fatty acids and human colonic function: Roles of resistant starch and nonstarch polysaccharides. Physiol. Rev. 2001, 81, 1031-1064. [CrossRef] [PubMed] 